\title{
Література:
}

1. Конституція України: Закон України від 21 січня 1994p. № 3856-XII-BP / Верховна рада України. Відомості Верховної Ради України. 1994. № 16. Ст. 93.

2. Васін В.А., Власов И.Б., Егоров Ю.М. Информационные технологии в радиотехнических системах / под ред. И. Б. Федорова. 2-е изд., перераб. и доп. М. : Изд-во МГТУ им. Н. Э. Баумана, 2004. $-768 \mathrm{c}$.

3. Шевкопляс Б. В. Скремблирование передаваемых данных. Журнал «Искусство схемотехники», № 3, 2005. Ст. 30-33.

DOI https://doi.org/10.30525/978-9934-588-79-2-1.22

\section{АНАЛІЗ ПРОБЛЕМИ ВДОСКОНАЛЕННЯ МОДЕЛЕЙ, МЕТОДІВ ТА ІНФОРМАЦІЙНИХ ТЕХНОЛОГІЙ КОМП'ЮТЕРИЗОВАНОГО НАВЧАННЯ В ПРЕДМЕТНІЙ ГАЛУЗІ МОБІЛЬНИХ ПРИСТРОЇВ, ТЕХНОЛОГІЙ І СИСТЕМ}

\author{
Ходаков В. $\mathbf{G .}$ \\ доктор технічних наук, професор, \\ заслужений діяч науки і техніки Украӥни \\ Морського інституту післядипломної освіти \\ імені контр-адмірала Ф. Ф. Ушакова \\ Веселовська Г. В. \\ кандидат технічних наук, дочент, \\ дочент кафедри інформачійних технологій
} Херсонського начіонального технічного університету

Кучмійчук М. М.

аспірант першого курсу кафедри інформаційних технологій Херсонського національного технічного університету м. Херсон, Украӥна

Для нинішнього стану суспільств та економік світу властиве суттєве фактичне збільшення та тенденція до подальшого інтенсивного зростання інформаційних об'ємів, необхідних для отримання студентами належного рівня фахових компетенцій, що дозволять їм мати високу та тривалу конкурентну здатність як професіоналам на ринку праці. 
Особливо проблемним зазначений аспект $є$ для великих швидко прогресуючих предметних галузей, де теоретичні та практичні інновації виникають практично кожного дня. Наочним прикладом таких галузей $є$ IT-сфера та найрізноманітніші напрями іiі безпосереднього практичного застосування (комп'ютерно-орієнтоване та базоване на прогресивних інформаційних технологіях проектування промислових виробів, моделювання наукових експериментів, проведення медичних досліджень, здійснення дизайну тощо).

Важливою проблемою $є$ знаходження нових витоків для значного підвищення продуктивності та досягнення найбільш адекватної змістовності інформаційного насичення майбутніх фахівців під час розвинення в них актуальних професійних компетенцій.

Одним із шляхів зазначеного пошуку є вдосконалення методів, моделей та інформаційних технологій комп'ютеризованого навчання, що надає потужні можливості для кращого та швидшого засвоєння знань, набуття більш усвідомлених і стійких умінь і навичок на засадах використання високо наочного мультимедійного, гіпермедійного й інтерактивного контенту навчального призначення.

Незважаючи на велику кількість досліджень і розробок у сфері застосування прогресивних інформаційних технологій комп'ютеризованого навчання в освітніх процесах, ще не всі предметні галузі охоплено зазначеною методологічною підтримкою в потрібному обсязі та на належному рівні вивченості, впорядкованості та системності.

Зокрема, до названої категорії належить одна 3 найсучасніших $\mathrm{i}$ найбільш запитуваних предметних галузей, що інтегрує актуальні знання в царині мобільних пристроїв, технологій і систем.

Представлені вище міркування обумовлюють у цілому високу актуальність, практичну цінність і необхідність привнесення наукової новизни до досліджень і розробок щодо моделей, методів та інформаційних технологій комп'ютеризованого навчання в предметній галузі мобільних пристроїв, технологій і систем [1-2].

У рамках вище означеної тематики досліджень і розробок, основними проблемами, що важливо вирішувати надалі, є наведені нижче наслідки високої динаміки збільшення інформаційного простору досліджуваної предметної галузі.

По-перше, маємо проблему суттєвої надлишковості інформаційних обсягів предметної галузі (через наявність дублювання інформації, неактуальних відомостей, інформації-спаму тощо) та, в підсумку, об'єктивну неможливість ознайомлення зі всією накопиченою інформацією, що робить певну частину інформації незатребуваною. Зазна- 
чене обумовлює необхідність автоматизованої фільтрації найбільш доцільної інформації освітнього призначення на засадах інтелектуалізованих методів і засобів, таких як інтелектуальні програмні Internet-агенти, що працюють на основі технологій спеціалізованих експертних систем.

По-друге, має місце слабка структурованість предметної галузі, обумовлена іï недостатньою вивченістю. Вказане тягне за собою необхідність побудови відповідних класифікаційних схем та ієрархій у вигляді навантажених семантичних мереж.

По-третє, недостатньо вивченою $є$ семантика предметної галузі, що вимагає створення й узагальнення для неї полів знань.

По-четверте, обрана предметна галузь за фактом є дослідженою лише на мікро-рівнях, відсутні належні загальні системні дослідження в ній, що потребує їхнього проведення на макро-рівні.

Підсумовуючи вище сказане, актуальність досліджуваної теми обумовлює наступне: тісна асоційованість зі сферою інформаційних технологій комп'ютеризованого навчання, що на сучасному етапі розвитку соціально-економічних процесів і науково-технічного прогресу є одним із пріоритетних напрямів удосконалення системи освіти; щільна пов'язаність із пошуком резервів підвищення ефективності опановування однієї з найсучасніших галузей знань, що дозволяє надати людській життедіяльності потрібної мобільності; те, що, на даний час, вона ще не отримала належної підтримки всебічними системними дослідженнями.

У свою чергу, практичну цінність дослідження за питаннями створення моделей, методів та інформаційних технологій комп'ютеризованого навчання в предметній галузі мобільних пристроїв, технологій і систем обумовлює високий попит ринку праці на фахівців, які теоретично та практично володіють розвиненими компетенціями в указаній предметній галузі.

В якості фундаментальних підгрунть досліджуваної теми, виступають такі методологічні та практичні напрацювання: достатньо ретельно опрацьовані загальні питання комп'ютеризованого навчання та використання, в межах його здійснення, прогресивних інформаційних технологій; суттєво розвинений стан галузі людських знань щодо мобільних пристроїв, технологій і систем.

Разом із тим, методологічна та прикладна опрацьованість питання про інформаційні технології комп'ютеризованого навчання в предметній галузі мобільних пристроїв, технологій і систем $€$ незначною. 
В основному, мова йде про конкретні практичні розробки на кшталт мультимедійних енциклопедій, хрестоматій, довідників, демонстраційних програм тощо, котрі унаочнюють розгляд особливостей конкретних мобільних пристроїв, технологій і систем.

Велику частку зазначених розробок пропонують фірми-виробники мобільних засобів із рекламними, а не освітніми цілями.

Методологічні ж напрацювання $є$ нечисленними, переважно стосуючись тих мобільних пристроїв, технологій і систем, що можуть бути застосовані в якості технічних засобів навчання, й орієнтовані в основному на ознайомлення з ними викладачів.

Передбачувана наукова новизна результатів досліджень бачиться в необхідності та можливості здійснення посиленого системного підходу до вирішення проблеми створення моделей, методів та інформаційних технологій комп'ютеризованого навчання в предметній галузі мобільних пристроїв, технологій і систем.

Виходячи 3 вище сказаного, за головну мету дослідження, було взяте знаходження шляхів для підвищення ефективності інформаційних технологій комп'ютеризованого навчання в межах предметної галузі мобільних пристроїв, технологій і систем на засадах посилення системного підходу до вибору, інтеграції, аналізу, моделювання, створення, вдосконалення та застосування зазначених технологій.

Зважаючи на вище означену мету дослідження, передбачається подальше вирішення таких ключових завдань: розширений аналіз сучасного стану актуальних проблем у сфері комп'ютеризованих інформаційних технологій навчання в предметній галузі мобільних пристроїв, систем і технологій; поглиблений аналіз і моделювання комп'ютеризованих інформаційних технологій навчання в предметній галузі мобільних пристроїв, систем і технологій у межах загальносистемних аспектів їхнього розгляду; дослідження семантичного компоненту комп'ютеризованих інформаційних технологій навчання в предметній галузі мобільних пристроїв, систем і технологій.

Висновки: поставлено, проаналізовано та окреслено загальні напрямки вирішення проблеми вдосконалення моделей, методів та інформаційних технологій комп'ютеризованого навчання в предметній галузі мобільних пристроїв, технологій і систем.

\section{Література:}

1. Ходаков В.С., Кругла Н.А., Веселовська Г.В., Кучмійчук М.М. Дослідження актуальних аспектів створення інформаційних технологій комп'ютеризованих систем навчання в предметній галузі проекту- 
вання мобільних додатків. Передові наукові розробки - 2020: Матеріали XVI Міжн. наук.-практ. конференції (Чехія, Прага, 22 серпня 2020 р.). Прага: Видавничий Дім "Education and Science", 2020. Volume 5.68 c. С. $60-62$.

2. Ходаков В.С., Кругла Н.А., Веселовська Г.В., Кучмійчук М.М. Аналіз семантичної складової інформаційних технологій комп'ютеризованого навчання проектуванню мобільних додатків. Передові наукові розробки - 2020: Матеріали XVI Міжн. наук.-практ. конференції (Чехія, Прага, 22 серпня 2020 р.). Прага: Видавничий Дім "Education and Science", 2020. Volume 5. 68 c. C. 63-65.

DOI https://doi.org/10.30525/978-9934-588-79-2-1.23

\section{МЕТОДИКА ОЦІНЮВАННЯ РІВНЯ КІБЕРНЕТИЧНОЇ БЕЗПЕКИ МЕРЕЖ СПЕЦІАЛЬНОГО ПРИЗНАЧЕННЯ}

\section{Чевардін В. С.}

доктор технічних наук, старший науковий співробітник, начальник кафедри захисту інформачії та кіберзахисту Військового інституту телекомунікацій та інформатизації імені Героїв Крут

Мазулевський О. $\mathbf{C}$. кандидат технічних наук,

доиент кафедри захисту інформаиії та кіберзахисту Військового інституту телекомунікаиій та інформатизаиіі імені Героїв Крут

\section{Сова О. Я.}

доктор технічних наук, старший науковий співробітник, начальник кафедри автоматизованих систем управління Військового інституту телекомунікаиій та інформатизаиіі імені Героїв Крут м. Київ, Україна

Вступ. Досвід операцій (бойових дій) останніх років свідчить про зростаючу роль інформаційно-телекомунікаційних систем (ITC) спеціального призначення у досягненні мети операції (бойових дій).

Специфічність ITC спеціального призначення полягає в тому, що з однісї сторони вони вирішують завдання передачі та обробки інфор- 